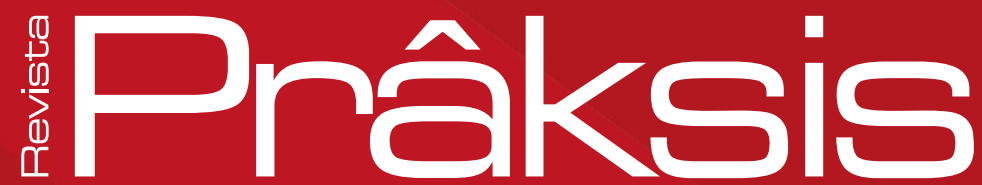

p-ISSN: 1807-1112

e-ISSN: 2448-1939

Recebido em: 24 de setembro de 2018 Aprovado em: 15 de dezembro de 2018 Sistema de Avaliação: Double Blind Review RPR |a. 16 | n. 1 |p. 169-185|jan./abr. 2019

DOI: https://doi.org/10.25112/rpr.v1i0.1785

\title{
ELISEU CÉsAR E AS "ALGAS" DE UM POETA NEGRO
}

\section{ELISEU CÉSAR AND THE "ALGAS" OF A BLACK POET}

\section{Elio Chaves Flores}

Doutor em História pela Universidade Federal Fluminense (Niterói/Brasil). Professor da Universidade Federal da Paraíba (João Pessoa/Brasil)

e Bolsista Produtividade em Pesquisa (CNPq).

\section{Solange Pereira Rocha}

Doutora em História pela Universidade Federal de Pernambuco (Recife/Brasil).

Professora da Universidade Federal da Paraíba (João Pessoa/Brasil).

\section{Petrônio Domingues}

Doutor em História pela Universidade de São Paulo (São Paulo /Brasil).

Professor da Universidade Federal de Sergipe (Brasil) e Bolsista Produtividade em Pesquisa (CNPq)

E-mail: pjdomingues@yahoo.com.br 


\section{RESUMO}

O artigo se debruça em torno da produção literária de Eliseu César, um "homem livre de cor", que nasceu na Paraíba em 1871. Embora tivesse crescido sob a vigência ainda do sistema escravista, este intelectual negro não tinha vínculos diretos com o cativeiro, o que de certo modo the facultou mais possibilidades para fazer carreira como jornalista, advogado e político. 0 artigo examina, particularmente, o seu livro de poesias, Algas, lançado em 1894, no contexto de consolidação da jovem República brasileira. O livro representou um marco na afirmação do autor como "homem de letras".

Palavras-chave: Negro. Raça. Cidadania. Pós-abolição. Literatura.

\section{ABSTRACT}

The article focuses on Eliseu César's literary production. He was a "free black man" who was born in Paraíba in 1871. Although he grew up under the still existing slave system, this black intellectual had no direct bonds with captivity. This provided him more possibilities to make a career as a journalist, a lawyer and a politician. The article examines, in particular, his book of poems, Algas, released in 1894, in the context of the consolidation of the young Brazilian Republic. The work represented a milestone in the author's claim as a "man of letters".

Keywords: Black. Race. Citizenship. Post-abolition. Literature. 


\section{INTRODUÇÃO}

Eliseu Elias César (1871-1923) nasceu na Cidade da Parahyba (denominada atualmente de João Pessoa), então capital de uma das Províncias do Norte, em 21 de julho de 1871. Apesar de sua origem negra e ter vindo ao mundo dois meses antes da aprovação da Lei Rio Branco (mais conhecida como Lei "Ventre Livre", promulgada em 28 de setembro de 1871), ele e sua mãe não eram cativos. Quanto ao seu pai, consta que se chamava Dulcídio Augusto César, fazia parte dos $38,5 \%$ da população branca da Província (ROCHA, 2015, p. 184-87) e teria assumido posicionamentos abolicionistas. 0 "moleque Eliseu" não foi criado pela mãe, cujo destino permanece desconhecido, mas pela avó materna, Vicência Ferreira de Albuquerque César, que o acolheu no seu "lar virtuoso. Criou-o com o maior desvelo. Mandou-o para a escola. Ensinou-Ihe religião, sentimentos" (NÓBREGA, 1955, p. 280). Eliseu teria granjeado uma formação letrada, tendo feito o "preparatório" no Lyceu Paraibano. ${ }^{1}$ Caminhada pouco comum para crianças e jovens negros na última década da escravidão no Brasil.

Cedo começou a trabalhar como tipógrafo, num ambiente de aprendizes e artífices, embebidos de tipos móveis, provas e impressões. Mais tarde, tornou-se "praticante dos Correios". Nesse ínterim, lançou-se ao mercado das letras nas oficinas dos jornais da Parahyba do Norte. Iniciando-se como bardo com apenas dezesseis anos, Eliseu publicou poemas e folhetins em, pelo menos, sete desses jornais - Sorriso (1886-1887), Arauto Parahybano (1888), O Cisne (1889), O Estado (1889/1890), O Parahybano (1892), O Artista (1895) e O Estado do Parahyba (1891-1894), onde também atuou como colaborador.

O jovem afro-paraibano aderiu à causa republicana e, diante da queda da Monarquia e do advento da República, em 15 de novembro de 1889, encheu-se de esperanças de que a nova forma de governo pudesse garantir conquistas no campo dos direitos e da cidadania, além de promover uma renovação política na nação. Com tal espírito, foi em 1892 um dos fundadores do Club Cardoso Vieira - uma associação cívicoliterária de orientação republicana -, onde fez parte da diretoria, ocupando o cargo de orador (ROCHA, 2012).

Em 1895, Eliseu se transferiu para o Recife (PE), a fim de cursar a Faculdade de Direito. A partir dali, levou uma vida em trânsito, diaspórica. Quando se aproximava do término do curso superior, tornouse promotor público na cidade de Vitória do Espírito Santo; em seguida, estabeleceu-se em Belém do Pará, onde se dedicou ao jornalismo, à advocacia e fez carreira política, ocupando o cargo de secretário da Intendência Municipal de Belém e de deputado estadual (1909). Depois, mudou-se para o Rio de Janeiro, onde atuou como jornalista e advogado. Ainda teve uma breve passagem por Santos (SP), mas

\footnotetext{
1 Sobre o universo letrado e a educação da população negra na Parahyba do Norte, durante o século XIX, ver a recente pesquisa
} de BARROS (2017). 
acabou regressando à Capital da República, onde faleceu, inesperadamente, em 1923, com 51 anos de idade. Mesmo sendo considerado um intelectual competente e dotado de uma cultura invulgar, o afroparaibano, ao longo da vida, colecionou dissabores relacionados à sua cor.

\section{UM ARCANO DA CIDADANIA NEGRA}

0 ano de 1894 foi intenso para o jovem poeta Eliseu César, então com 23 anos de idade. No dia 13 de maio, um domingo ensolarado, segundo notícia da imprensa local, ele participou dos festejos cívicos e militares em torno da data abolicionista. Fez discurso na solenidade que se realizou nas dependências do Teatro Santa Rosa. Subiu ao palco depois das 12 horas como um cidadão republicano. 0 mote básico de sua oratória foi tentar "mostrar que a liberdade era grandiosa não só pelo princípio da humanidade, como também pela igualdade das classes perante a lei e a sociedade" (A Ordem, Ano I, 19/05/1894). Esse discurso de efeméride, seis anos após a abolição da escravidão no Brasil, pode indicar uma data ainda cheia de ambiguidades, de ressonâncias de classes e subalternidades raciais, como demonstra anúncio de venda de um sítio nas imediações da cidade: "Acha-se à venda no Beco da Mãe dos Homens um sítio com 12 casas de palhas sendo três pertencentes ao mesmo sitio e as outras de moradores diversos, com muitos coqueiros, bananeiras, abacaxis, e outras qualidades de fruteiras" (Estado da Paraíba, Ano V, 31/01/1894). Não seria difícil imaginar que esses cultivadores de terras, camponeses negros, saídos da escravidão e "moradores em casas de palhas" acabassem vendendo frutas variadas nos espaços urbanos por onde transitava o poeta Eliseu César, especialmente nas oficinas tipográficas, nas redações de jornais e na agência central do Correios.

Autor de poesias desde os dezessete anos, publicadas em vários jornais da Província/Estado, Eliseu César preparou o seu primeiro (e único) livro literário com um total de 58 poemas e atribuiu-lhe 0 título Algas (1894), hoje obra rara nos acervos paraibanos.² As poesias, nenhuma nominada com essa

\footnotetext{
${ }^{2}$ Nossas pesquisas sobre Eliseu César vinham sendo feitas com base nos estudos de memorialistas e na imprensa paraibana oitocentista no sentido de analisar a sua produção poética e sua trajetória intelectual. Por mais de cinco anos não havíamos conseguido localizar a obra Algas em nenhum acervo da Paraíba, Pernambuco e Rio de Janeiro (FLORES; DOMINGUES; ROCHA, 2017). No início de 2018, felizmente, localizamos um exemplar da obra na Biblioteca de Obras Raras Átila Almeida da Universidade Estadual da Paraíba (UEPB) em Campina Grande. Agradecemos o apoio de bibliotecária da Fundação José Américo de Almeida (João Pessoa), que localizou o referido livro no catálogo da Biblioteca Átila de Almeida (UEPB-Campina Grande) e nos informou por telefone. Em seguida, contamos com o auxílio de Germana Guimarães Gomes, que também pesquisa a "gente negra" na Paraíba. A historiadora é autora da obra Insultos, elogios e resistências: participação de repentistas negros em cantorias no Nordeste (1870-1930). João Pessoa: UFPB/CCHLA/PPGH, 2012. [Dissertação de Mestrado]. Ela esteve na Biblioteca Átila de Almeida e obteve uma cópia de Algas.
} 
expressão, são precedidas de um estudo crítico-literário - intitulado "em vez de prologo" -, assinado pelo político, advogado e jornalista João Pereira de Castro Pinto, formado pela Faculdade de Direito do Recife (Turma de 1886), que havia participado como deputado da Assembleia Constituinte da Paraíba (1891/92) e também atuava nas lides literárias e jornalísticas. ${ }^{3}$

Castro Pinto assina o prefácio com data de 1 de junho de 1894 e, empolgado, escreve o dístico nos parágrafos finais: "A Parahyba tem um poeta. Graças Ihe sejam dadas" (CASTRO PINTO, 1894, p. IX). 0 livro foi editado e impresso na Tipografia, Litografia, Encadernação e Pautação de Jayme Seixas \& Cia, com um total de 146 páginas, cujas poesias podem ser tipificadas em quatro dimensões: a lírica (amor, mulher, paisagem); social (profissão, sofrimento, religião); política (drama, acontecimento, sujeitos); e racial (moreninha, mulatinha, tranças). Nesse trabalho daremos ênfase nas categorias política e racial. Essa chave interpretativa é usada aqui como um experimento metodológico e não incide sobre todos os poemas do livro.

Nas últimas décadas os textos literários passaram a ser vistos pelos historiadores como materiais propícios a múltiplas leituras, especialmente por sua riqueza de significados para o entendimento do mundo cultural, dos valores sociais e das experiências subjetivas de homens e mulheres no tempo. O caráter polifônico dos textos literários, pelo diálogo que estabelecem entre as diferentes vozes das personagens, além da voz do narrador, possibilita mergulhar na complexidade do imaginário histórico, da diversidade de ideologias e dos modos como os diferentes indivíduos ou grupos sociais representaram questões (desejos, expectativas, utopias ou frustrações) relacionadas à raça, à classe e às relações de gênero. Como argumenta Roger Chartier, "algumas obras literárias moldaram, mais poderosamente que os historiadores, as representações coletivas do passado" (CHARTIER, 2009, p. 25). Motivo a mais para estes não negligenciarem os laços, atados, emaranhados ou soltos, entre a narrativa histórica e a narrativa literária.

O historiador, que se debruça em torno de fontes literárias, deve procurar entrelaçar análise textual (interna) e contextual (externa). 0 que caracteriza a operação historiográfica é a interpretação das fontes em determinadas circunstâncias sociais, isto é, nos contextos. De acordo com essa concepção, "texto e contexto não configuram polos incomunicáveis, ao contrário, é possível ler as marcas da sociedade e da cultura no interior dos escritos, e de outro, compreender o significado deles na sociedade" (FERREIRA, 2009, p. 82).

\footnotetext{
3 João Pereira de Castro Pinto (1863-1944) também foi Deputado Federal (1906-1908) e Senador (1908-1912) e Presidente do Estado da Paraíba (1912-1915), cf. Mariz (1987, p. 63-66) e Nóbrega (p. 94-95).
} 
No que tange à poesia, como fonte histórica, também se faz necessário a intepretação da forma e do conteúdo das obras, ou seja, requer que sua análise interna seja articulada ao mundo circundante. A poesia permite reporta-se às imagens e representações tecidas pelos sujeitos em cada contexto, com toda sua carga de sentidos e significações sociais, culturais, identitárias e simbólicas. Alfredo Bosi destaca esse poder do vate: "Então vem o poeta e divisa na massa amorfa que passa pela rua a figura humana, mulher, homem, velho, jovem, criança; em um relance, o que era sombra errante vira gente" (BOSI, 2013, p. 10).

Depois desse arrazoado sobre o uso da literatura na pesquisa histórica, voltemos ao livro de Eliseu César. Já por ocasião de seu lançamento, Algas repercutiu para além do Estado da Parahyba. Uma resenha publicada no Jornal do Recife julgava que a obra padecia de "descuidos e alguns erros" estilísticos, porém reconhecia que "há também quem os escreva piores e goze apesar disto de fama e proveito" (Jornal do Recife, Ano XXXVII, 14/10/1894, p. 2). Seja como for, Algas constitui uma espécie de marco na vida do intelectual afro-paraibano. Por um lado significou sua afirmação no "mundo das letras" - chancelada ao longo de sua trajetória pelas lides jurídicas, jornalísticas e pela constante contribuição em periódicos paraibanos e de alhures. Por outro, o livro representou uma grande oportunidade desse intelectual expressar publicamente seus talentos, sentimentos e ideais. Nesse período ele se valeu de versos para dar os tons de suas concepções identitárias, propostas e projetos políticos e estéticos.

Não por acaso o leitor que em 1894 folheasse o seu livro de poesias, sem saber absolutamente nada sobre o autor e tampouco sobre sua obra, encontraria logo nos primeiros versos elementos que informariam sobre o que iria vislumbrar ao longo de sua leitura. No entanto, o título aparecia como intrigante. Por que essa breve expressão, "algas"? 0 autor, ao que parece, silenciou sobre a escolha e o prefaciador não deu nenhuma pista. Castro Pinto anota que "o paradigma de produções" do poeta "se encontra na natureza ambiente" e pontua a "sua idiossincrasia de mestiço" (CASTRO PINTO, 1894, p. VIII). A linha interpretativa não pode descartar o viés romântico e lírico - gênero literário em voga naqueles anos -, quem sabe também o simbolista. No poema "Felicitação", oferecido a um amigo que completava aniversário, Eliseu César tem como metáfora o mar, o movimento das águas, mas não é explícita a palavra algas: "Não sei porque do mar as vagas doudejantes/Têm hoje sobre a fronte espumas cintilantes" (CÉSAR, 1894, p. 22). Outras imagens do mar e das águas não soam estranhas num livro que abarcava, pelo menos, uma década de produção poética. Entretanto, o explícito é "voar às regiões distantes", isto é, "além do mar, além da serrania" (CÉSAR, 1894, p. 119).

Nesse tom de expressão lírica afro-brasileira "algas" se afigura, então, no torvelinho da renovação da vida marinha e das cercanias do mar. Se é ainda possível buscar correntes literárias para escritores afrobrasileiros emparedados pela sociedade racializada, Cruz e Sousa, ao publicar Broquéis [1893], chega a 
burilar uma definição para "algas" no poema "Flor do mar", cujas passagens simbolistas são significativas: "És da origem do mar, /Vens do secreto [...]/Surges das águas mucilaginosas [...]/Acres aromas de algas e sargaços" (CRUZ E SOUSA, 1997, p. 42). Ao final do Oitocentos, o século da biologia, parecia corrente que as expressões "algas e sargaços" denotavam a flora marinha em regiões e litorais tropicais. Foram vistas como "extrações líricas" (BARBOSA FILHO, 1987, p. 76), quando encaixadas nas vertentes e nas gerações do romantismo poético brasileiro (BOSI, 1994, p. 109-133). Podemos pensar em extrações líricas de amores racializados, por que não? ${ }^{4}$

A partir de nossa primeira definição, romântica ou lírica (predominante em Algas), podemos alinhavar poemas como "Súplica", "Uma saudade", "Saudade", "Belezas gêmeas", "Gotas de ouro", "Vendo-te", "Versos a ela", "Versos postais" e "Uns versos". Este último abre-se com um monólogo entre o narrador e uma mulher que se encontram através da poesia: "Dizeis, senhora, amar a poesia, / Essa cantante e florea primavera/ [...] Amai-a, sim, que a poesia é como/ Um perfume sutil, todo frescor..." (CÉSAR, 1894, p. 97). Em "Gotas de ouro" o poeta associa o amor, a mulher às primeiras letras (um registro caro à lírica afro-brasileira), isto é, ao acesso à educação letrada: "Que as estrelinhas serenas/ Do amor à doce mercê/ Soletrem, juntas contigo, /Cantando e rindo - A, B, C" (CÉSAR, 1894, p. 84). Esse apego pelas letras e palavras deve-se, certamente, ao exercício profissional de tipógrafo e praticamente dos correios, que permitiram a Eliseu César uma trajetória pelas sociabilidades literárias. ${ }^{5}$ Com efeito, está lá, na lírica de Eliseu César, esse registro romântico em "Versos postais". 0 autor começa associando o rosto da mulher amada (ou desejada ou idealizada) à carta que the escreve em que carimba o envelope com um beijo; a mala postal é o afeto, toda lacrada com amor; o recinto da alma seriam os segredos dos correios; os lábios são pura etiqueta, imaginados pelo poeta. Vem então o fechamento: "Enfim, tu és meu cuidado, /O coração do meu seio, /Etiqueta, lacre, carta, / Porque pertenço ao correio" (CÉSAR, 1894, p. 142). Percebe-se que as nossas categorias não respondem à polissemia das fontes poéticas, antes são definições que se cruzam. No caso acima, é o amor romântico do poeta e a profissão de praticante dos correios na Cidade da Parahyba (DOMINGUES; FLORES; ROCHA, 2017). ${ }^{6}$

\footnotetext{
${ }^{4}$ Por que os escritores afro-brasileiros do século XIX aderiram facilmente ao romantismo? Pergunta Roger Bastide, talvez o primeiro pesquisador a usar a expressão "poesia afro-brasileira". Eis a sua resposta: "Eles aí encontraram desde o princípio tudo que encontravam os brancos, uma satisfação sentimental. E ainda uma satisfação que lhe era própria, a da igualdade racial" (BASTIDE, 1943, p. 44).

${ }^{5}$ Sobre esse percurso de Eliseu César, ver Flores; Domingues; Rocha (2017), Rocha; Flores (2015), Rocha (2015).

${ }^{6} \mathrm{O}$ ofício de "praticante dos Correios" predizia o início de um aprendizado social e de contatos pessoais com novas sociabilidades e alargamento da visão de mundo. Ao que tudo indica, esse segundo ofício também recebeu a influência do pai de Eliseu César, que chegou a exercer o cargo de administrador dos Correios em duas províncias do Norte, a Paraíba e o Rio Grande do Norte. Podemos problematizar nesse sentido: Dulcídio Augusto César pensou em preparar o filho para o "serviço público" e, talvez, para uma carreira que lhe permitisse ascensão social na jovem República.
} 
Vinculemos então ao argumento social - nossa segunda caracterização - alguns poemas, entre outros, "Um coração", "A lágrima", "Ruínas", "Igrejinha", "Ante uma cruz", "Lacrim/e", "Ingenuidade". 0 argumento social pode ser sempre contextualizado, posto que a literatura é um testemunho histórico (CHALHOUB; PEREIRA, 1998, p. 7). Poetas e poesias devem ser vistos inseridos na arena das polêmicas, disputas e conflitos de sua contemporaneidade, são sujeitos e personagens das narrativas versejadas. Como salienta Alfredo Bosi, não basta simplesmente datar a fonte poética. Deve-se levar em conta, também, que as questões de cada tempo, de uma forma ou de outra, são "operante em cada poema".7

Para Eliseu César o índice social começa pela família e pelo papel da mãe, particularmente. 0 poema "Um coração" remete ao amor divinizado da mãe, a mulher que o "afasta da senda do martírio". Com efeito, na retórica romântica mãe e mulher constituem a ambivalência do final do século: "Não é, porém, o coração da virgem/ Por quem eu vivo a suspirar também, /O coração que traz-me na vertigem, / No êxtase do amor divinizado, /É o teu, celeste mãe" (CÉSAR, 1894, p. 4). Dois índices entrelaçam no poema de abertura de Algas: o livro é dedicado à memória de sua mãe adotiva, Dona Vicencia Ferreira de Albuquerque César, na verdade sua avó materna, mãe do seu pai, Dulcídio Augusto César; mas ele era filho natural de Maria Joaquina de Freitas, mulher negra cuja trajetória pouco se conhece. Pela afirmação "mãe adotiva" na dedicatória, entende-se que o poema não consegue omitir o reverso, a "mãe natural" que não deixa de ser, também, "cofre feito para guardar os prantos". Na dimensão das "ruínas" da infância, da "juventude morta", e no tempo presente da poesia, o "castelo derrocado" quando tudo era antes "verde palmeiral". Assim é o discurso sobre a "igrejinha", do repicar dos sinos para os misseiros: "a missa, a missa, os aldeões chamando", espaço de sociabilidade que ficou na memória de infância" (CÉSAR, 1894, p. 19-21; p. 24-25).

Dessa religiosidade cândida brota certo desespero, a "suspensão desoladora da crença", como podemos indiciar perante a cruz, na lágrima e na ingenuidade. Vejamos. "Ante uma cruz" o poeta sente horror, sente-se pequeno, espanta-se. Ele, na verdade, "cisma nesse drama tinto em sangue" e congemina de novo "na treva dessas horas mudas". O desfecho é humilhante para a divindade e para a criatura, pois "ante esta cruz, alevantada, imensa" apenas enxerga-se um "pálido Jesus" (CÉSAR, 1894, p. 31-32). O prefaciador cunha uma frase que capta essa atmosfera da vida no final do Oitocentos: "A arte, como a religião, parece ser a companheira eterna da indústria e da ciência" (CASTRO PINTO, 1894,

\footnotetext{
7 Para Alfredo Bosi, "contextualizar o poema não é simplesmente datá-lo: é inserir as suas imagens e pensamentos em uma trama já em si mesma multidimensional; uma trama em que o eu lírico vive ora experiências novas, ora lembranças de infância, ora valores tradicionais, ora anseios de mudança, ora suspensão desoladora de crenças e esperanças. A poesia pertence à História Geral, mas é preciso conhecer qual é a história peculiar imanente e operante em cada poema" (BOSI, 2004, p. 13).
} 
p. VI). O poema "Lacrim/e" fala do infortúnio, do enterro e das "tristes irmandades", levando ao "pouso derradeiro" o primeiro afeto, donde um registro da perda da mãe - mas qual mãe, a adotiva ou a natural? - "Caixão que vai, fantástico e moroso, /Leva ao sepulcro minha mãe finada?" (CÉSAR, 1894, p. 81). No poema "Ingenuidade", uma palavra por vezes recusada pela historiografia brasileira é sugerida, a mulher camponesa. Não há evidência de marcador racial. Mas, naqueles sítios quem plantava e fazia germinar? Naquelas casas de palha, quem habitava? Naquelas nesgas de terras verdejantes (e talvez assoladas), quem colhia e quem semeava culturas de subsistência? Eliseu César se desmancha nessa lírica: "Eu nunca deixarei por outra graça/ Tua graça real de camponesa". O bardo alude à "custodia dos campos", aos ares enfeitiçados nas festas domingueiras, ao verde à beira dos caminhos, e oblitera: "E quando alguém disser que não te amo, / Oh! minha linda camponesa idolatrada" (CÉSAR, 1894, p. 115-16). A imagem obliterada pode descortinar um traço de continuidade histórica no germinar da temporalidade poética (pós-abolição), em se tratando de mulher camponesa e mulher camponesa negra quase sempre implica em "histórias de liberdade".

Fixemo-nos na categoria de poemas de registros políticos, entre outros: "Christo", "General Barreto", "Silva Jardim". Podeparecer estranho figurar aqui Jesus Cristo (6/4a.c. - 30/33d.c.) ao lado de personalidades contemporâneas ao poeta. Entretanto, trata-se de um Cristo histórico, criatura incompreendida no seu tempo, cuja verve romântica do bardo desce-o dos céus abstratos para a terra da "louca multidão". Com dezesseis estrofes, o poema "Christo" discorre sobre um homem que "semeava o bem", porém, a "mina das paixões, dos ódios, inflamava". Esses ódios vinham da "louca multidão" e da "infrene agitação das cóleras". O poeta ilumina "o traiçoeiro Judas", também humano, nesse evento fundador de uma religião localizada que foi "um doloroso transe". Deveras, tu, Cristo sentistes, diz o poeta, a "humana ingratidão cuspir-te sobre as faces". A sexta estrofe dramatiza o escárnio da história, decerto que a história antiga, oriental e romanizada: "Haviam de rasgar-te as carnes, te arrastando / Sobre as pedras, assim como se arrasta um cão... / E o quadro dessa dor imensamente grande / Havia de alertar um riso à multidão". Mas eis que, então, um nome "encheu de repente as terras da Judéia" e o piedoso Cristo é arrancado da aurora e o poeta apressa a história: "Para ti vão abrir os braços de uma cruz". Na décima primeira estrofe, Eliseu César imagina um Cristo na ambiguidade "herói/maldito", semelhante às revoltas negras contra a opressão escravista, tão bem descortinadas pela recente historiografia: "Eis que soa o tropel: a multidão revolta / Acusa-te, Jesus: tu és um criminoso! / Utopista do amor, a Lei jamais consente / Que vagueie pela estrada um grande revoltoso!" (CÉSAR, 1894, p. 51-54). Não há como escamotear uma possível analogia do "grande revoltoso" nas estradas com as lutas de resistência escrava travadas nas últimas décadas da Monarquia. A última estrofe recolhe, do tempo presente do poeta, a visada da liberdade e a 
quebra dos grilhões da opressão, sim, a alegoria desse Cristo sofredor é a do escravo libertado: "Deixoute em recompensa à morte que lhe deste, / Oh! triste, criminosa e ingrata Humanidade! / Quebrados os grilhões que os pulsos te feriam, / E a curva de ouro e azul do céu da Liberdade!". Percebemos aqui sinais das imagens simbolistas de Cruz e Sousa, outro poeta negro, contemporâneo ao próprio Eliseu (FLORES, 2015). Seja como for, o autor de Algas faz de seu "Christo" histórico um protagonista de sua própria humanidade.

O poema "General Barreto" parece dialogar com o contexto das lutas políticas republicanas e suas reverberações nas estruturas locais de poder. 0 general José de Almeida Barreto (1827-1905) nasceu na Parahyba, combateu na Guerra do Paraguai e foi um dos militares que participou do "golpe deodorista" que proclamou a República, tornando-se senador pela Paraíba. Barreto fez oposição (civil e militar) à ascensão "jacobina" de Floriano Peixoto e ficou na defesa do governador Venâncio Neiva, deposto, como tantos outros, com o golpe de 23 de novembro de 1891. Promovido a marechal em 11 de janeiro de 1892 foi, com essa patente, signatário do "Manifesto dos 13 Generais", no dia 31 de março de 1892. Nessas circunstâncias ganhou um efêmero exílio no Estado do Amazonas. 0 panegírico poético traça esse perfil militar "nos campos de batalha" ante as "agressões raivosas da metralha". Chega-se a "representar" o militar como "gênio da guerra, ocasião em que até "a morte recuava" e, assim, foi levado "para o céu da história". São fortes as pistas de que Eliseu César mantinha sociabilidades políticas com o grupo republicano do poder local apoiado nacionalmente pelo General Barreto. O laudatório chega a esses últimos acontecimentos: "Mais tarde ei-lo no exílio, mas, no entanto, / O seu vulto eletriza, enche de espanto / E cresce ainda mais: É como o sol que às orlas do poente / [...] Ostenta a rubra face surpreendente" (CÉSAR, 1894, p. 28-30). 0 desterro do General Barreto durou de abril a setembro de 1892 e o poeta não perdeu a oportunidade para retratar, idealmente, o "revoltoso" que "audazmente animava o tiroteio".

O poema "Silva Jardim" talvez seja o mais ideologicamente republicano dessa série política. Trata-se da verve trágica da performance romântica. Antônio da Silva Jardim (1860-1891) foi o maior ícone do projeto de uma República jacobina, que atendesse às aspirações populares, e o poeta vai construir essa representação na dimensão de um acontecimento traumático. Como se sabe, Silva Jardim foi tragado pelas fendas do Vesúvio, nas proximidades de Nápoles (Itália), no dia 01 de julho de 1891. A morte do jacobino republicano repercute largamente na imprensa local nos meses seguintes. Esse é o contexto 
do poema. ${ }^{8}$ Com apenas quatro estrofes o "Silva Jardim" de Eliseu César pega a história por um fio. Na primeira o passamento: "Morreste, lutador, quando da glória / Brilhava-te na fronte um raio louro... / Morreste, mas de estrelas um tesouro / Hoje redoira as páginas da história". Na segunda estrofe, a construção de um "herói" da jovem República: "Foi-te a existência um campo de batalha, / Onde lutaste em prol da liberdade, / Na loucura febril da heroicidade / impávido titã, riste à metralha". Na terceira estrofe, o poeta remete às pelejas políticas, aos esplendores e ao apoio da multidão. Silva Jardim foi um republicano muito popular, especialmente no Rio de Janeiro, São Paulo e Minas Gerais. A expressão "ativista" dos ideais republicanos não Ihe soa anacrônica. Na última estrofe, Eliseu César replica a cena da morte de Silva Jardim no Vesúvio: "Após tanto lutar, atleta ousado, / Como um condor que tomba fulminado, / Foste cair na entranha d'um vulcão" (CÉSAR, 1894, p. 26-27).

O Vesúvio que soterrou Pompeia, Herculano e Stabia foi dramatizado na imprensa paraibana ao tragar o corpo de Silva Jardim. Os republicanos da Cidade da Parahyba celebraram a sua passagem trinta dias depois (O Estado da Parahyba, 12/08/1891). Nessa mesma edição Eliseu César publica "Loucura" numa extensão do drama do Vesúvio: "Vê bem: aquele Cristo amargurado" (CÉSAR, 1894, p. 104). Tanto em âmbito nacional quanto na dimensão das culturas políticas locais a República, antes provisória, afirmavase numa "loucura" de eventos que arrastavam as elites e os intelectuais dos espaços de poder e das redações para as ruas. Em boa medida, entre 1891 e 1894, Eliseu César publica num frenesi poético que impressiona. A trajetória do vate caminha, igualmente, no chão da política republicana. Nada lembra os correligionários da "Guarda Negra" na Corte imperial. Nesse contexto, Eliseu César é um poeta engajado com as questões de seu tempo, um "homem de cor republicano" e, portanto, deve ser visto "para além dos negros monarquistas" (DOMINGUES, 2014, p. 148-150).

Com a perspectiva indiciária do registro racial constam "Os meus poemas", "Teus beijos", "Moreninha", "Mulatinha". Nos dois primeiros poemas expressões sinuosas denotam, talvez, abstrações raciais amorosas e, nos dois últimos, sinais de uma identidade racial aparecem na idealização da mulher. No longo "Os meus poemas" (cinco partes), o autor reitera a ideia de "mulher morena". O coração do vate está "tonto de luz e de amores" e o diz nessa expressividade romântica: "E teus olhos.. (ai! Morena!) / Celestes, almos, tão puros... / D'uma alegria serena... / São dous brilhantes escuros". Desfilam-se versos sobre as faces, os olhos, a boca, o diapasão da vontade de beijos, as possibilidades de afetos e todo "um

\footnotetext{
${ }^{8}$ As notícias começam a aparecer no dia 03 de julho e se estendem até o mês de agosto. O Estado da Parahyba, 03/07/1891; 26/07/1891; 04/08/1891; 12/08/1891; 14/08/1891; 19/08/1891; 21/08/1891; 23/08/1891; 29/08/1891. Os registros poéticos sobre Silva Jardim e o Vesúvio foram reiterados. José do Patrocínio parece que foi o primeiro: "Bela sepultura o vulcão, extraordinário destino o do grande brasileiro; até para morrer converteu-se em lava" (O Século, 12/07/1891). Ver Hardman (1998).
} 
lirismo sorridente" com toques erotizados. A evocação da "morena" se repete: "A tua boca pequena / Que verte a essencia dos lyrios / eis a origem, morena, / Dos meus ardentes delirios!". Essa situação persiste na abertura do poema "Teus beijos", no qual denota uma ação amorosa dessa mulher abstrata: "Morena, teus castos beijos", cuja boca beijante inventa coisas sonoras, segreda frases de amor, sugerindo mundos estrelados e o "eu lírico" que tudo vê e sente "À sombra das tuas tranças" (CÉSAR, 1894, p. 135-140; 14344). Pode ser que uma mulher de tranças não denote "traço étnico", mas, quando associado à expressão "morena", a margem para a etnicidade aumenta.

No poema "Moreninha", o amor é segredado, contido, sonhado. Outras palavras, que podemos designá-las como "marcadores étnicos", fazem da construção dessa lírica algo mais aproximativo de uma possível "identidade racial". A abertura "Moreninha, se soubesses" é reeditada em "Ah! Moreninha dos meus sonhos". Do olhar ao "pé formoso" outros indicadores étnicos passam pela estrofe: "Tua trança negra e pura, / A delicada cintura, / O brilho do teu olhar, / A noute do teu cabelo". Aqui observam-se sinais, traços, indícios da mulher negra (ou parda). A reiteração, para fechar o poema, implica a aura romântica, "Moreninha! Minha flor" (CÉSAR, 1894, p. 102-103). Parece pouco, mas não custa lembrar que a poesia de Eliseu César começa a ser escrita nas experiências das emancipações e do pós-abolição, praticamente no último quartel do século XIX. Decerto que, nessas experiências românticas racializadas, também haveria de ter, como assinalou Roger Bastide, "amores de negros e amores de brancos" (BASTIDE, 1943, p. 75-80).

Apresentamos, agora, o poema "Mulatinha", com oito estrofes que joga enfoque lírico com evidentes emblemas de identidade racial. Para melhor fruição do leitor, vamos citar na íntegra a primeira, a segunda e a quinta estrofes, onde a situação indiciária aventa imagens poéticas da mulher negra visada:

Vejo-te a um canto amuada, Bem como a flor desbotada Pelo calor do verão...

Minha bella mulatinha, Que aguda magua espezinha Teu ridente coração?

Acaso a côr do teu rosto É que produz o desgosto Que assim te faz padecer? Ah! Tu nem sabes, florinha, Que essa côr de mulatinha Faz a gente enlouquecer! 
Não queiras nunca ser branca,

Pois tens um olhar que arranca

Muito doido coração:

Tens d'esse olhar nas scentelhas

A doçura das abelhas

E as garras do gavião (CÉSAR, 1894, p. 127-129).

Podemos notar que o foco narrativo gira em torno da valorização étnica da personagem central, na medida em que reconhece a beleza estética da "bella mulatinha", em detrimento da mulher branca ("não queiras nunca ser branca"). A visada do poeta é que a "mulatinha" está "amuada" e indaga se é por causa de sua "cor", que na pena do vate é positivada. Essa interpelação reconhece a pertença étnica, para não dizer a identidade racial da protagonista do verso, e advoga a beleza da sua cor, a beleza da mulher afrobrasileira.

"Mulatinha" faz lembrar os versos líricos de "Meus Amores" (1865), de Luiz Gama, outro poeta negro da segunda metade do XIX e autor do livro Primeiras trovas burlescas de Getulino (1904 [1859]). Em "Meus Amores", Gama faz uma descrição das formas de uma "formosa crioula, ou Tethis negra". Celebra o corpo da mulher negra, valorizando e exaltando sua beleza". Não promove apenas a transposição dos valores estéticos das pessoas brancas para a sua "Tethis negra"; mais que isso, os versos deste poema induzem o leitor a uma comparação. A mulher negra é retratada "de um ponto de vista que singularizava e privilegiava sua beleza em contraposição às formas femininas das mulheres brancas" (AZEVEDO, 1999, p. 65).

Se em 1865 Luiz Gama já versejava questionando o símbolo ocidental da beleza feminina, por que Eliseu César, um negro "empoderado", não haveria de imprimir à sua produção poética a anelagem que imaginava, almejava e romantizava acerca das relações raciais no Brasil? Por que não pensar esse poema, "Mulatinha", como uma espécie de sismógrafo que registrou, em versos, expectativas identitárias e urdiduras multifacetadas da "mulher negra"? Seria anacronismo falarmos em "literatura negra" no século XIX? O termo "literatura afro-brasileira" seria o mais pertinente? Essas polêmicas estão em curso no tempo presente (CUTI, 2010, DUARTE; FONSECA, 2011).

Tomamos essa hipótese de Oswaldo de Camargo, que observa o enorme desafio para os escritores negros (e pardos) do século XIX ultrapassarem a "inflexão racializada da linguagem". A valorização explícita da beleza dos marcadores étnicos da mulher negra "recém-saída do cativeiro" seria, na concepção de Camargo, "literariamente louvável, de acordo com as normas [líricas], uma dicção cheia 
de negrice" (CAMARGO, 2005, p. 15). Assim, a expressão "mulatinha", no verso de Eliseu César, quer nos parecer que seja uma reconfiguração poética daquele que apresentamos antes, "moreninha". Pois há mais intersecções. Na sexta estrofe, sinais diacríticos, que numa década antes apareciam nos anúncios de jornais como traços de "mulher negra escrava fugida", agora reverberam, na lírica do bardo, o sentido afirmativo da negrura, "Esse teu cabelo anelado" segue-se pelo olhar erotizado - mas não folclorizado nem naturalizado - do "Teu quadril arredondado". Não existe razão para despistarmos o romantismo racializado de Eliseu César, ao contrário, pensamos em inscrevê-lo, tanto nos domínios de clio quanto nos da história da literatura brasileira. ${ }^{9}$ Tendemos a concordar com Roger Bastide, quando postula que o romantismo "é o momento da primeira eclosão da poesia afro-brasileira. Por isso mesmo ele é muito interessante de se estudar, para ver-se em que medida se adquiriu a consciência de uma originalidade estética racial" (BASTIDE, 1943, p. 40).

A historiografia contemporânea reconhece que a literatura pode contribuir para o conhecimento das experiências individuais e coletivas de homens e mulheres no tempo. Afinal, a história também comporta "dimensões subjetivas, imaginárias, oníricas e ficcionais, tão importantes quanto os acontecimentos políticos, sociais e econômicos" (FERREIRA, 2009, p. 84). Ainda assim, a historiografia precisa prestar mais atenção ao uso da poesia como fonte para o estudo da experiência negra no Brasil. 0 poeta e pesquisador contemporâneo Cuti (Luiz Silva) tem algo a nos dizer a respeito. Havia, mesmo no ocaso do século XIX, um "estreito corredor das letras" para mulheres e homens afro-brasileiros. A conjugação de talento, oportunidades, redes de sociabilidades e clientelas poderia levá-los a certo prestígio e reconhecimento, desde que inseridos nos circuitos sobretudo românticos. 0 mundo das letras não era apanágio das pessoas brancas. Assim, o método historiográfico deve ter como caminho "desemparedar" a escrita negra oitocentista, seguir o "ventre livre das obras" e trazer à tona o "sujeito étnico", com suas "referencialidades e transgressões" (CUTI, 2009, p. 97-107). No seu conjunto literário, Algas (1894) nos permitiu testar essa abordagem e problematizar aspectos da produção poética negra para a historiografia.

Na obra, Eliseu César utiliza uma linguagem e forma literária tradicionais, e por isso mesmo legitimada e socialmente aceita pelo grupo que a ela tem acesso, para exaltar alguns valores externos a esse grupo social. 0 tom conferido pelo escritor afro-paraibano a seus poemas, longe de apenas reificar uma imagem de vitimização das personagens, presumivelmente ligada às memórias e agruras do cativeiro, conduzia o leitor a urdiduras afro-brasileiras mais amplas, nuançadas e valorizadas em alguns de seus aspectos

\footnotetext{
${ }^{9}$ Mesmo pesquisas clássicas e ontologias e coletâneas contemporâneas, que se dedicam à temática da "raça" e "cor" na literatura brasileira, negligenciam a escritura de Eliseu César, sequer mencionando a existência do livro Algas (Ver, entre outros, Sayers, 1958; Rabassa, 1965; Brookshaw, 1983; San|Tos; Galas; Tavares; 2005, Duarte; Fonseca, 2011).
} 
culturais e estéticos. É verdade que a experiência negra não assume centralidade em Algas, porém tal perspectiva não foi escamoteada pelo autor, que se valeu de versos poéticos para abordar múltiplas experiências, como uma pessoa negra, mas também como "homem de letras" e protagonista de sua história - e de seu tempo. ${ }^{10}$ Afora reafirmar a literatura como lugar de embate de ideias e de problematização social e política, o volume de versos acenava para outro tipo de identidade. Aliás, Eliseu César soube se apropriar naquele momento de códigos que circulavam no "mundo letrado", transformando-os em um canal para vocalizar seus ideais, de um Brasil republicano e livre das prevenções de "casta" e "cor".

\section{REFERÊNCIAS}

AZEVEDO, Elciene. Orfeu de carapinha: a trajetória de Luiz Gama na imperial cidade de São Paulo. Campinas, SP: Editora da Unicamp; Cecult, 1999.

BARBOSA FILHO, Hildeberto. Eliseu César. In: CASTRO PINTO, Sérgio de (Org.). Coletânea de autores paraibanos. João Pessoa: Estada da Paraíba, 1987, p. 76-77.

BARROS, Surya Aaronovich Pombo de. Universo letrado, educação e população negra na Parahyba do Norte (século XIX). Tese (Doutorado em Educação) - Faculdade de Educação. Universidade de São Paulo, 2017.

Ser negro na Parahyba do Norte: cores, condições, qualidades e universo letrado no século XIX. Estudos Ibero-Americanos, Porto Alegre, v. 44, n. 3, 2018, p. 494-500.

BASTIDE, Roger. A Poesia Afro-Brasileira. São Paulo: Livraria Martins Editora, 1943.

BOSI, Alfredo. Entre a literatura e a história. São Paulo: Editora 34, 2013.

O ser e o tempo da poesia. São Paulo: Companhia das Letras, 2004.

História concisa da literatura brasileira. São Paulo: Cultrix, 1994.

\footnotetext{
${ }^{10}$ Sobre ser negro no universo letrado da Parahyba do Norte no século XIX, ver BARROS (2018).
} 
BROOKSHAW, David. Raça \& cor na literatura brasileira. Porto Alegre: Mercado Aberto, 1983.

CAMARGO, Oswaldo de. Poesia negra e uma visão reveladora do Brasil. In: SANTOS, Luiz Carlos dos; GALAS, Maria; TAVARES, Ulisses (Org.). 0 negro em versos: antologia da poesia negra brasileira. São Paulo: Editora Moderna, 2005, p. 11-20.

CASTRO PINTO, João Pereira de. Em vez de Prologo. In: CÉSAR, Eliseu. Algas. Parahyba: Typ. Lith. Encadernação e Pautação de Jayme Seixas \& C., 1894, p. V-IX.

CÉSAR, Eliseu. Algas. Parahyba: Typ. Lith. Encadernação e Pautação de Jayme Seixas \& C., 1894.

CHALHOUB, Sidney; PEREIRA, Leonardo Affonso de M. Apresentação. In: CHALHOUB, Sidney; PEREIRA, Leonardo Affonso de M (Org.). A história contada: capítulos de história social da literatura no Brasil. Rio de Janeiro: Nova Fronteira, 1998, p. 7-13.

CHARTIER, Roger. A história ou a leitura do tempo. Belo Horizonte: Autêntica, 2009.

CRUZ E SOUSA, João da. Os melhores poemas de Cruz e Sousa. São Paulo: Global Editora, 1997. Broquéis [1893], p. 25-47.

CUTI, Luiz Silva. A consciência do impacto nas obras de Cruz e Sousa e de Lima Barreto. Belo Horizonte: Autêntica Editora, 2009.

Literatura negro-brasileira. São Paulo: Selo Negro, 2010.

DOMINGUES, Petrônio. Cidadania levada a sério: os republicanos de cor no Brasil. In: GOMES,

Flávio; DOMINGUES, Petrônio (Org.). Políticas da Raça: experiências e legados da abolição e da pósemancipação no Brasil. São Paulo: Selo Negro, 2014, p. 121-154.

DOMINGUES, Petrônio; FLORES, Elio Chaves; ROCHA, Solange P. De poeta a patrono literário: fragmentos da vida de Eliseu César (1871-1923). Anais... XXIX Simpósio Nacional de História. ANPUHBrasil; UnB, Brasília, 2017, p. 01-11.

DUARTE, Eduardo de Assis; FONSECA, Maria Nazareth (Org.). Literatura e Afrodescendência no Brasil: antologia crítica. Vol. 4 (História, Teoria, Polêmica). Belo Horizonte: Editora UFMG, 2011.

FERREIRA, Antonio Celso. Literatura: a fonte fecunda. In: PINSKY, Carla Bassanezi; LUCA, Tania Regina de (Org.). 0 historiador e suas fontes. São Paulo: Contexto, 2009, p. 61-91. 
FLORES, Elio Chaves. Entre ilhas e sertões: um século, temporalidade vária, protagonismo negro. In: CURY, Cláudia Engler; GALVES, Marcelo Cheche; FARIA, Regina Helena Martins de (Org./ 0 Império do Brasil: educação, impressos e confrontos sociopolíticos. São Luís: Editora UEMA; Editora Café \& Lápis, 2015, p. 475-511.

GAMA, Luiz. Trovas burlescas de Getulino. 3. ed. São Paulo: Tipografia Bentley Júnior, 1904 [1859]. GOMES, Germana Guimarães. “Insultos", “Elogios" e "Resistências": participação de repentistas negros em cantorias no Nordeste (1870-1930). 2012. 178 f. Dissertação (Mestrado em História) Centro de Ciências Humanas, Letras e Artes, Universidade Federal da Paraíba, 2012.

HARDMAN, Francisco Foot. Siva Jardim: a República e o vulcão. Estudos Avançados, v. 12, n. 34, set./dez. 1998. MARQUESE, Rafael; SALLES, Ricardo (Org.). Escravidão e capitalismo histórico no século XIX. Rio de Janeiro: Civilização Brasileira, 2016.

NÓBREGA, Seráphico. Discurso de Posse na Academia Paraibana de Letras. Revista Academia Paraibana de Letras, João Pessoa, n. 6, 1955.

RABASSA, Gregory. 0 negro na ficção brasileira: meio século de história literária. Rio de Janeiro: Edições Tempo Brasileiro, 1965.

ROCHA, Solange P. ROCHA, Solange P. Cardoso Vieira, um homem negro na composição das Elites da Paraíba oitocentista: biografia, memória e história. Crítica Histórica, Macéio, a. III, n. 6, dez., 2012, p. 01-18. . População, compadrio e trajetórias de gente negra na Cidade da Paraíba Oitocentista.

Saeculum: Revista de História (UFPB), v. 33, jul./dez., p. 183-199, 2015.

FLORES, Elio Chaves. Trajetórias comparadas de homens negros de letras na Paraíba: ensino de história, biografias e sociabilidades. In: OLIVEIRA, Ariosvalber de Souza; SILVA, Moisés Alves da; AIRES, José Luciano de Queiroz (Org.). Nas confluências do Axé: refletindo os desafios e possibilidades de uma Educação para as relações Étnico-raciais. João Pessoa: Editora do CCTA, 2015, p. 143-183.

SANTOS, Luiz Carlos dos; GALAS, Maria; TAVARES, Ulisses (Org.). 0 negro em versos: antologia da poesia negra brasileira. São Paulo: Editora Moderna, 2005.

SAYERS, Raymond S. 0 negro na literatura brasileira. Rio de Janeiro: Edições O Cruzeiro, 1958.

XAVIER, Giovana; FARIAS, Juliana Barreto; GOMES, Flavio dos Santos (Org.). Mulheres negras no Brasil escravista e do pós-emancipação. São Paulo: Sele Negro, 2012. 